\title{
Language Features Used to Describe Major Character in Short Stories
}

\author{
Eka Puspita1, Azwandi², Irma Diani ${ }^{3}$ \\ ${ }^{123}$ English Education Postgraduate Programe \\ Bengkulu University, Indonesia \\ e-Mail: puspitaeka398@gmail.com \\ azwandi58@yahoo.com irmabengkulu@yahoo.com
}

\section{ABSTRACT:}

Language Features are the important aspect in a text. This is part of the student's knowledge. If the students familiar with the language features, they can understand the major characters in the texts easily. The purpose of this study is to analyze the language features that used to describe major characters in short stories. This research was a descriptive qualitative research. The research objects were taken at six Indonesian short stories and six English short stories. The research procedure classifies all objects based on language features of research instruments. The results of this study are there are two characters of major character in the short stories, protagonist and antagonist. In Indonesian short stories there are two short stories that have antagonist characters and four short stories have protagonist characters. And all of the short stories only have one major character. But in English short stories, four of the short stories have two major characters and two short stories only have one major character.

Keywords: Language Features, Short Stories, Characters, Major Characters

\section{ABSTRAK:}

Ciri-ciri kebahasaan merupakan aspek yang penting dalam sebuah teks. Ini merupakan bagian dari ilmu pengetahuan yang dimiliki siswa. Jika siswa mengenal ciri-ciri kebahasaan, mereka bisa memahami tokoh utama dalam cerita pendek. Tujuan dari tesis ini adalah untuk menganalisis ciri kebahasaan yang digunakan untuk menggambarkan tokoh utama dalam cerita-cerita pendek. Penelitian ini adalah penelitian deskriptif kualitatif. Objek penelitian diambil dari enam cerita pendek Indonesia dan enam cerita pendek Inggris. Prosedur penelitian adalah dengan mengklasifikasikan semua objek berdasarkan ciri kebahasaan dalam instrument penelitian. Hasil penelitian ini adalah: Ada dua karakter tokoh utama yaitu protagonis dan antagonis. Pada cerita pendek Indonesia, ada dua cerita pendek yang memiliki karakter antagonis dan empat cerita pendek yang empunyai karakter protagonis, dan semua cerita pendek hanya memiliki satu tokoh utama. Tetapi pada cerita pendek Inggris, ada empat cerita yang mempunyai dua tokoh utama dan dua cerita yang mempunyai satu tokoh utama.

Key Words : Language Features, Short Stories, Characters, Major Characters

\section{INTRODUCTION}

Short story is a brief, imaginative narrative, unfolding a single predominating incident and a single chief character; it contains a plot, the details of which are so compressed, and the whole treatment so organized, as to produce a single impression. (Esenwein, 1909: 51). The short story is a literary genre. It is usually fictional narrative prose, as well as another form of fictional stories, short story is also established by intrinsic elements such as ; theme, character, setting, plot, stylistic, and point of view. The related issues on analysing short stories have been discussed in some graduating papers and journals. As seen in Adera (2012), in his 
thesis Adera stylistically analyses four of Edgar Allan Poe's short stories: Three Sundays in a Week, The Black Cat, A Tale of Jerusalem, and Shadow. He uses Foregrounding as a theoretical framework for his analysis.

The second study was conducted by Adane (2012), Adane says due to time constraint the analysis focuses only on three selected chapters that are considered to be stylistically representative in the novel. The novel has a total of sixteen chapters. Adane takes lexical categories and figures of speech as theoretical framework for his analysis.

The third study was conducted by Segara (2013), Segara found that the students did not use one or more features in their narrative text and the students applied and ignored when writing narrative text and factors that made students ignored features of narrative text.

The fourth study was conducted by Buechner (2015), She explore writing to evaluate the nature of creativity in the English field, explaining certain techniques that writers must learn, identifying struggles they must overcome, and including tips from editors on publishing fiction.

The last study was conducted by Alemu (2015), He found that very limited number of theses dealing with stylistic analysis of short stories and none of them deals with any of 0 Henry's works. Since the research is theoretical, analytical and descriptive in nature, close reading and text based analysis are applied in the analysis of the short stories.

The finding from Adera (2012) same with Adane (2012) and Alemu (2015). Adera analyse the stylistic in four short story but Alemu just one short story. Adane analyses stylistic only focuses on three selected chapter in a novel. Unlike finding from Segara (2013) and Buechner (2015) just analyse the narrative text features and Buechner just analyse the writing analysis in short story.

The above studies are important in order to know about the language features However; none of those studies above focus on language features in major characters in short stories. Therefore, the researcher choose short stories for children, especially folktales and legends because, first, beside it is a part of English material in Junior High School, the short stories like folktales and legends needed to be introduce to the learners for enriching and showing differences genres and text types. Second, by showing different genre or text such as folktales and legends, it may also influence specific characters to the learners. ".From the background above, the research formulated problems. Of the research follow:

1. What language features did the authors used to describe the major characters in Indonesian short stories?

2. What language features did the authors used to describe the major characters in English short stories?

3. How are the major characters characterized in Indonesian and English short stories?

\section{METHOD}


research is Qualitative study that uses descriptive content analysis since
data is in the form of text. Maxwell (1996) argues that qualitative study
focuses on certain events or people emphasizing not on numbers, but more on words.

\section{Data Source}

The source of the data in this study is gathered from some short stories. The writer uses twelve short stories as main data. The data are taken from the text books and internet that are relevant and support the data of this research. The short stories consist of six folktales from Indonesian short stories and six folktales from English short stories. The short stories are taken from eight text books. In one text books have four until five folktales and legend. Some of them are fable, but researcher just takes the short story of fairy tales or legends. The short stories are The legend of Kemaro island, Malin Kundang, The Crying Stone, Timun Emas, Wa Lancar and The Legend of Rawa Pening. The English short stories are Beauty and the Beast, The Golden Star Fruit Tree, The Woodman and His Children (Henzel and Gretel), Mangita and Larina, The Empty Pot, and The Prince and his Best Friends.

This instrument was adapted from Leech and Short (1992). According to the model of analysis used by Leech and Short, and can choose one or a few issues to focus on in an analysis of their four categories of linguistic analysis. The researcher has chosen to focus on one, namely lexical categories.

Table of language feature's instruments

\begin{tabular}{|l|l|l|l|}
\hline \multicolumn{4}{|c|}{ Language Features } \\
\hline Nouns & Verbs & Adjectives & Adverbs \\
\hline & & & \\
& & & \\
& \multicolumn{3}{|c|}{ Adapted from Leech and Short (1992) } \\
\hline
\end{tabular}

This instrument was adapted from Leech and Short (1992). According to the model of analysis used by Leech and Short, and can choose one or a few issues to focus on in an analysis of their four categories of linguistic analysis. The researcher has

chosen to focus on one, namely lexical categories.

\section{Method of Data Analysis}

In this study, the writer use content analysis. Content analysis is applied to the analysis of data in documents and refers to the systematic description, description of the contents of documents. Four common uses for content analysis are:

1. To describe the relative frequency and importance of certain topics

2. To evaluate bias, prejudice or propaganda in pint materials.

3. To assess the level of difficulty in reading materials, and

4. To analyse types of errors in students' work.

\section{RESULTS AND DISCUSSION}

\section{short stories}

Language features used by authors to describe major characters in Indonesian

1. Timun Emas

The language features can see from the following table: 
Table 1. Timun Emas short story

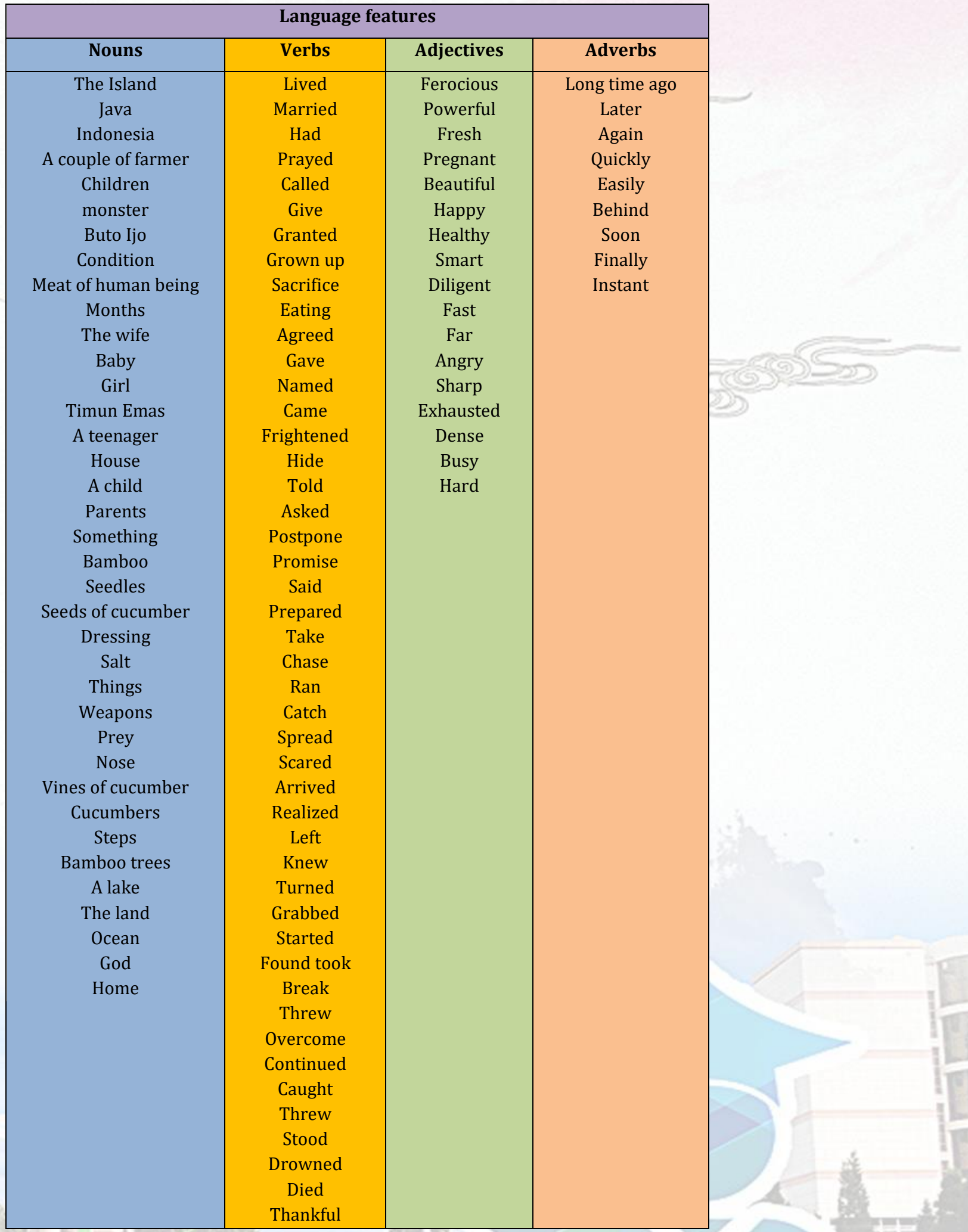

From the table above, researcher analyze that verbs are the greatest number of language features. The choice of verbs contributes clearly to the depiction of characters as heroes or villains, and it appears that there is association between "positive" verbs and "good" characters. The second numbers of the language features are nouns, in this short story, noun consist of proper nouns such as, Timun Emas, Buto Ijo and Indonesia. Common nouns such as, the island, children, monster, ocean, etc. Collective nouns such as, a couple of farmer, meats of 
human being, seeds of cucumber, and vines of cucumber. Material nouns such as, bamboo, seeds, etc The third numbers of language features are adjectives. The adjectives used in describing a character are very important. The type of adjectives consists of physical appearance such as, beautiful and pregnant. And personality adjectives such as, ferocious, powerful, smart, dilligent, etc The last numbers of language features are adverbs. The researcher analyze that the types of adverbs that used in this short story are adverb of manner such as, quickly, easily and finally. Adverb of time such as, long time ago, later, and behind, and adverb of frequency such as, again and soon.

\section{Malin Kundang}

Malin Kundang is a popular legend from West Sumatera, Indonesia. In this short story, the language features can be seen in the table as follows:

Table 2. Malin Kundang short story

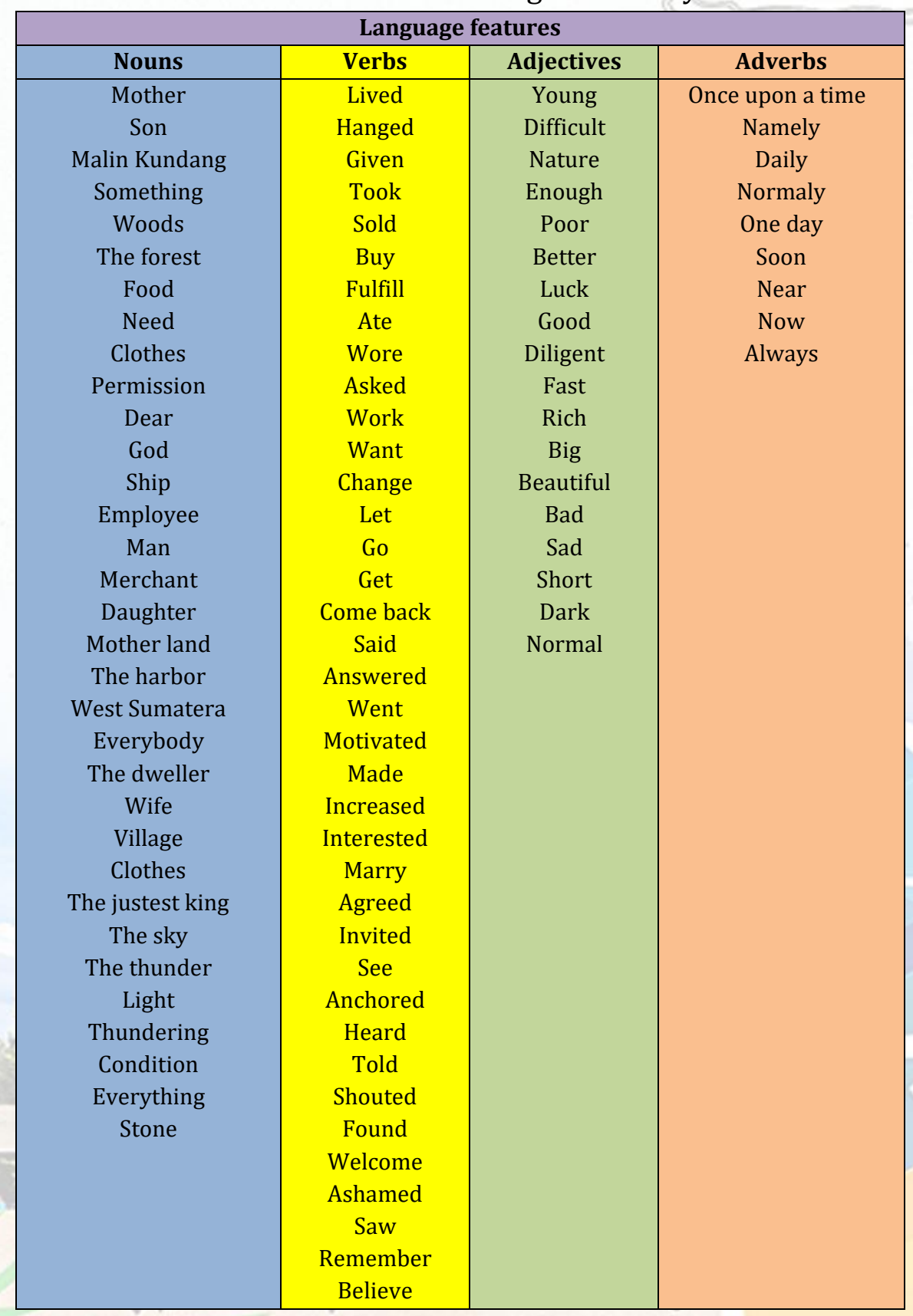




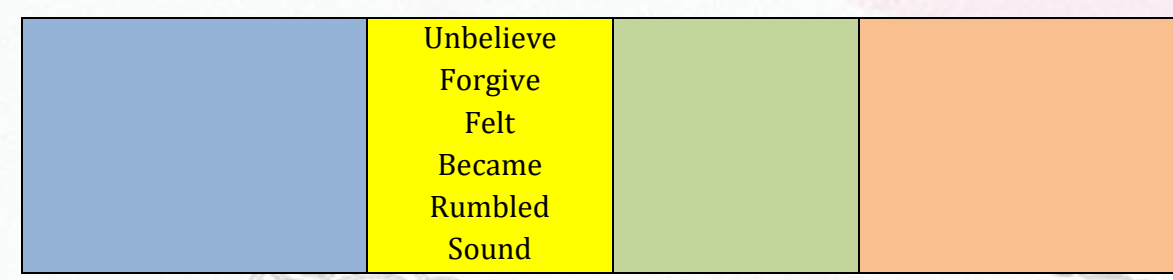

From the table above verb is the greatest number of language features, the researcher analyze that verbs in the text can show the characters, it can see from the verbs such as, ashamed, saw, go have no. The second numbers of language features is nouns. In this text noun consist of proper noun suc as, Malin Kundang. The common noun such as, the merchant, ship, daughter. The last is material noun such as, stone. The third number of language features is adjectives. The adjectives use physical appearance such as, young. The personality adjective such as, diligent. The fourth number of language features is adverbs. Adverb which is used in this text are adverb of manner such as, daily, normaly. Adverb of place such as, near. Adverb of time such as, soon. And adverb of frequency such as, always

\section{The Legend of Kemaro Island}

The Legend of Kemaro Island is a popular legend from South Sumatera. From the short story, the language features can be seen from the table as follows:

Table 3. The Legend of Kemaro Island short story

\begin{tabular}{|c|c|c|c|}
\hline \multicolumn{4}{|c|}{ Language features } \\
\hline Nouns & Verbs & Adjectives & Adverbs \\
\hline A kingdom & Fell & Beautiful & A long time ago \\
\hline South Sumatera & Propose & Single & One day \\
\hline The king & Wanted & Young & Here \\
\hline Daughter & Marry & Rich & Then \\
\hline Siti fatimah & Arrived & Beauty & Often \\
\hline Man & Came & Richer & Really \\
\hline Courage & Planned & Patience & Finally \\
\hline A ship & Meet & Spirit & Secretly \\
\hline China & Stay & Hard & After a while \\
\hline The captain & Remember & Big & Top \\
\hline Tan bun ann & Share & Rotten & Later \\
\hline A prince & Give & Angry & Immediately \\
\hline Business & Said & Power & The bottom \\
\hline Merchant & Admired & Impatient & Again \\
\hline Months & Tried & Grave & Always \\
\hline The palace & Find & Bigger & Never \\
\hline King's permission & Asked & High & \\
\hline Half of profit & Knew & & \\
\hline Majesty & Made & & \\
\hline The people & Worked & & \\
\hline Information & Approached & & \\
\hline Son in law & Talked & & \\
\hline Love & Filled & & \\
\hline Thing & Wrote & & \\
\hline Nine big jars & Told & & \\
\hline Gold & Agreed & & \\
\hline A letter & Sent & & \\
\hline The parents & Cover & & \\
\hline
\end{tabular}




\begin{tabular}{|c|c|c|c|}
\hline The thieves & Looked for & \\
Vegetables & Surprised & & \\
The pier & Opened & & \\
Musi river & Saw & & \\
Stone & Looked & & \\
Mistake & Search & & \\
Guards & Threw & & \\
Message & Smashed & & \\
A pile of soil & Found & & \\
An island & Jumped & & \\
The water & Collect & & \\
& Waited for & & \\
& Became & & \\
& Drowned & & \\
\hline
\end{tabular}

From the table above, the greatest number of language features is verbs. In this short story, there are two characters. The first character is Siti Fatimah. The verbs can be show the character of Siti Fatimah such as, admired, work, fell, saw, waited for, wanted, jump and helped. The second character of this short story is Tan Bun Ann. The character of Tan Bun Ann can be seeing from the verbs as follow; cam, meet, ask, and propose. The second number of language features is nouns. The types of nouns which use in this text such as, Proper noun, common noun, collective noun and material noun. Proper nouns such as, Tan Bun Ann, Siti Fatimah. Common noun in such as, the king, daughter, man. Collective nouns such as, half of your profit, a pile of soil. The third number of language features is adjectives. Like the verbs and nouns, adjective is larger than adverb although it is only more one point. The adjectives that used by the author are physical appearance, personality and comparative adjective. The physical appearance such as, beautiful, single, young and beauty. The personality adjective that use in this short story such as, patience, spirit, angry, power and grave. The comparative adjective such as, richer and bigger. The last number of language features in this short story is adverbs. Adverbs that use in this story are adverb of manner, such as, really, finally, secretly and immediately. The next is adverb of place such as, here, top and bottom. Adverb of time can be see in the sentence such as, A long time ago, One day and. Later. Adverb of frequency such as, often and never

\section{$4 \quad$ The Crying Stone.}

The Crying Stone is a famous short stories from Kalimantan, Indonesia. From the text of short story above the language features can be following from the table below:

Table 4. The Crying Stone short story

\begin{tabular}{|c|c|c|c|}
\hline \multicolumn{5}{|c|}{ Language features } \\
\hline Nouns & Verbs & Adjectives & Adverbs \\
\hline Widow & Lived & Poor & Once upon a time \\
Village & Helped & Old & Never \\
Daughter & Want & Small & One day \\
Mother & Know & Beautiful & Finally \\
Problem & Put & Lazy & Behind \\
Make up & Wear & Arrogant & On the way \\
Clothes & Look & Best & Again \\
The market & Buy & Rich & Always \\
Food & Refused & Sad & Everytime \\
Everybody & Accompany & Beauty & Anymore \\
\hline
\end{tabular}




\begin{tabular}{|c|c|c|c|}
\hline Girl & Agreed & Curious & Suddenly \\
Woman & Go & Simple & Slowly \\
Dress & Walk & Sad & Already \\
Servant & Said & Ashamed & Too \\
People & Admired & Panic & Late \\
The pain & Asked & & Now \\
God & Answered & & Down \\
Girl's leg & Hear & & \\
Stone & Understand & & \\
The process & Met & & \\
Body & Hold & & \\
& Prayed & & \\
The upper parts of girl's body & Punish & & \\
& Turns & & \\
& Continues panic & & \\
& Forgive & & \\
& Cried & & \\
& Becomes & & \\
& See & & \\
& call & & \\
\hline
\end{tabular}

From the table above, the greatest number of language features is verbs. The first major character in this short story is a poor widow (a mother). It can be see from the verbs such as, hear, say, understand, hold, prayed, punish, The second major character is a daughter.It can see from the verbs such as, helped, want, know, said, asked. The second number of language features is nouns. The first kind of nouns in this short story is common nouns, such as, widow, village, and daughter. The second noun is collective noun such as, the upper part of the girl's body. The third noun is material nouns such as, dress, stone. The third number of language features is adverbs. There are four types of adverb which use in this text; the first is adverb of manner, such as suddenly, finally. The second is adver of place, such as, behind. The third is adverb of time such as, Once upon a time, now. The last adverb is adverb of frequency such as, again. The fourth number of language features is adjectives. The adjectives use personality and physical adjectives. The examples of personality adjective such as, lazy, arrogant, ashamed, panic. The example of physical appearance such as, poor, old, small, rich, beautiful.

\section{Wa Lancar}

Wa Lancar is a story from North Sumatera. The Language Features in this short story can be seen from the table as follow:

Table 5. Wa Lancar short story

\begin{tabular}{|c|c|c|c|}
\hline \multicolumn{4}{|c|}{ Language features } \\
\hline Nouns & Verbs & Adjectives & Adverbs \\
\hline Wa Lancar & Studied & Poor & Always \\
Man & Have & Young & Fortunately \\
Money & Go & Diligent & Several years \\
Preacher & Met & Hard & Later \\
Rice field & Willing & Enough & Again \\
Students & Teach & Hungry & Afterwards \\
A piece of advice & Return & Satisfied & Immediately \\
First preacher & Asked & Poor & Mysteriously \\
Second preacher & Help & Jealous & Next \\
Third preacher & Agreed & Angry & Apparently \\
\hline
\end{tabular}




\begin{tabular}{|c|c|c|c|}
\hline $\begin{array}{c}\text { A stone } \\
\text { A knife } \\
\text { Kids } \\
\text { Jealous Preacher } \\
\text { Palace } \\
\text { King } \\
\text { Lesson } \\
\text { Man } \\
\text { Daughter } \\
\text { Wedding receptionist } \\
\text { Guest } \\
\text { Hill } \\
\text { Foods } \\
\text { Preacher's advice } \\
\text { Stone } \\
\text { The hill } \\
\text { Soldiers } \\
\text { Hole } \\
\text { Bed } \\
\text { Centipede } \\
\text { Wife } \\
\text { Things } \\
\text { Father } \\
\text { Word } \\
\text { Everything } \\
\text { Mistakes }\end{array}$ & $\begin{array}{c}\text { Taught } \\
\text { Left } \\
\text { Thought } \\
\text { Gave } \\
\text { Eat } \\
\text { Wait } \\
\text { Wanted } \\
\text { Leave } \\
\text { adviced } \\
\text { Rest } \\
\text { Pay } \\
\text { Get } \\
\text { Grind } \\
\text { Thankful } \\
\text { Suffered } \\
\text { Passed } \\
\text { Made } \\
\text { Told } \\
\text { Remembered } \\
\text { Fell } \\
\text { Died } \\
\text { Took } \\
\text { Bought } \\
\text { Arrived } \\
\text { Sleep } \\
\text { finished } \\
\text { Killed } \\
\text { Woke } \\
\text { Surprise } \\
\text { Confessed } \\
\text { Punished }\end{array}$ & $\begin{array}{c}\text { Tired } \\
\text { Delicious } \\
\text { Hungry } \\
\text { Black } \\
\text { Lucky } \\
\text { Deep } \\
\text { Bad } \\
\text { True }\end{array}$ & $\begin{array}{c}\text { Following morning } \\
\text { Lucky } \\
\text { Suddenly } \\
\text { Soon }\end{array}$ \\
\hline
\end{tabular}

From the table above, the greatest number of language features is verbs. The character in this short story can we see from the verbs such as, wanted, help, say, told, confessed. The second number of language features is nouns. From the text, nouns consist of proper noun suc as, Wa Lancar. Common noun such as, the preacher. Collective noun such as, a piece of advice. And material nouns such as, stone, knife. The third number of language features is adjectives. The adjectives consist of physical appearance such as, young. And personality adjectives such as diligent. The last number of language features is adverb. Adverb in this short story use adverb of manner such as, Fortunately, Adverb of place such as next. Adverb of time such as Later. And adverb of frequensy such as, in the following morning.

\section{The Legend of Rawa Pening}

The Legend of Rawa Pening is a famous story from Central Java. The language feature of The Legend of Rawa Pening short story can be seeing in the table as follow;

Table 6. The Legend of Rawa Pening short story

\begin{tabular}{|c|c|c|c|}
\hline \multicolumn{4}{|c|}{ Language features } \\
\hline Nouns & Verbs & Adjectives & Adverbs \\
\hline Boy & Knocked & Little & Once upon a time \\
Village & Asked & Poor & Finally \\
Door & Cared & Hungry & Mockingly \\
Food & Help & Weak & Easily \\
Nobody & Gave & Generous & Suddenly \\
Woman & Wanted & Old & Now \\
\hline
\end{tabular}




\begin{tabular}{|c|c|c|c|}
\hline Shelter & Leave & Big \\
Meal & Pounding & Wooden & \\
Lesung & Reminded & Happy & \\
Mortar & Remember & Closer & Luck \\
Rice & Save & Huge & \\
Flood & Thanked & & \\
A boat & Continued & \\
Journey & Passing & \\
People & Saw & \\
The field & Gathering & \\
A stick & Came & & \\
The ground & Stuck & \\
Everybody & Challenged & \\
The crowd & Pull & \\
The hole & Tried & \\
Water & Succeded & \\
Lake & Laughed & \\
Rawa pening lake & Stepped & \\
Salatiga & Dumbfounded & \\
Central & Spouted & \\
Java & Stop & \\
Indonesia & Flooded & \\
& Saved & \\
& Told & \\
& Picked & \\
& Became & \\
\end{tabular}

From the table above, the greates number of language features are verbs, the character of this short story can be see from verbs as follows, knocked, asked, cared, helped, The second number of language features are nouns, in this short story noun consist of proper noun such as, Lesung, Rawa Pening,. Common nouns such as, People. Materials noun such as, stick. The third number of language features is adjectives. Adjectives which used in this short story are personality adjectives such as, hungry, weak, generous. The physical appearance such as, little. and comparative adjectives such as, closer. The fourth number of language features is adverbs, Adverbs in this short story such as, adverb of manner. For example, mockingly, easily. Adverb of time such as, once upon a time, now.

\section{Language features used by authors to describe the major characters in English short stories}

1. Mangita and Larina

Mangita and Larina is a fairy tale from Filipine. The language features of this story can be see from the table as follows:

Table 7. Mangita and Larina short story

\begin{tabular}{|c|c|c|c|}
\hline \multicolumn{4}{|c|}{ Language features } \\
\hline Nouns & Verbs & Adjectives & Adverbs \\
\hline The banks of the Laguna the Bai & Lived & Poor & Many years ago \\
Fisherman & Died & Beautiful & Night \\
Wife & Named & Black & Never \\
Daughters & Had & Dark & Cruelly \\
Mangita & Helped & Good & One day \\
Larina & Mend & Bright & Mockingly \\
Hair & Make & Little & Afterwards \\
Girl & Smile & Fair & Down \\
\hline
\end{tabular}




\begin{tabular}{|c|c|c|c|}
\hline 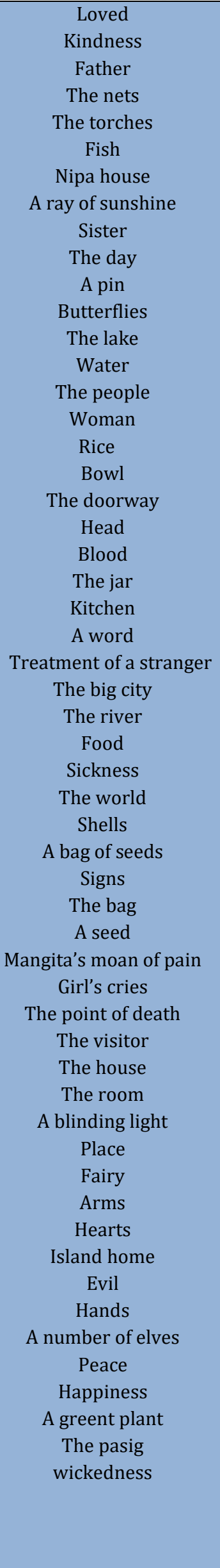 & 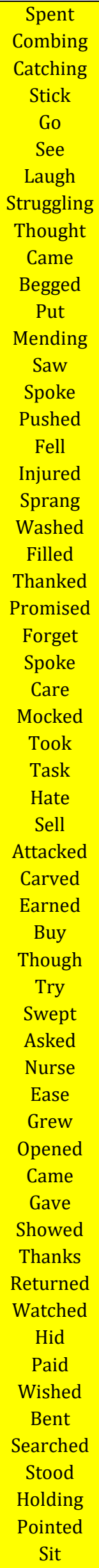 & $\begin{array}{c}\text { Long } \\
\text { Golden } \\
\text { Proud } \\
\text { Different } \\
\text { Pretty } \\
\text { Clear } \\
\text { Poor } \\
\text { Jealous } \\
\text { Old } \\
\text { Cruel } \\
\text { Alone } \\
\text { Enough } \\
\text { Worse } \\
\text { Kind } \\
\text { Weak } \\
\text { Alone } \\
\text { Weaker } \\
\text { Empty }\end{array}$ & $\begin{array}{c}\text { There } \\
\text { Now } \\
\text { Everywhere } \\
\text { Too } \\
\text { Finally } \\
\text { Soon } \\
\text { Again } \\
\text { Suddenly } \\
\text { Now } \\
\text { The bottom } \\
\text { This day }\end{array}$ \\
\hline
\end{tabular}

Sit 


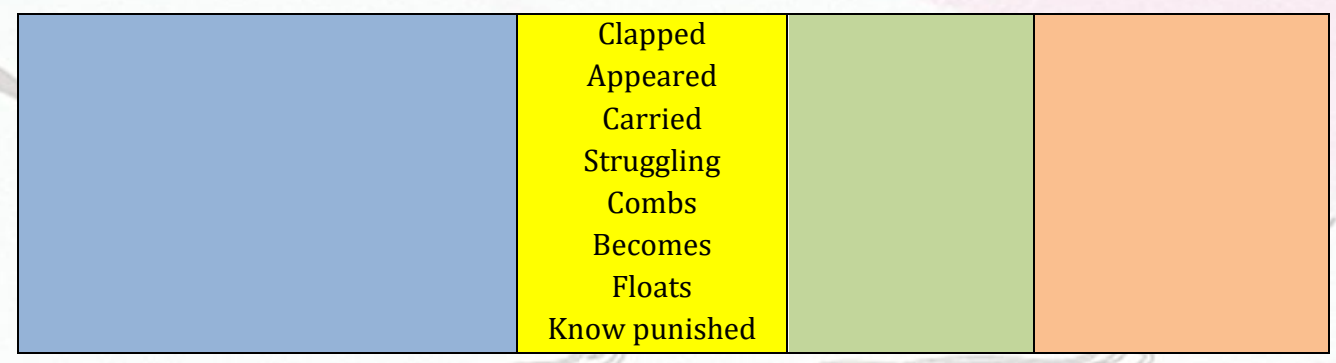

The largest number of language features is verbs. From the verbs in the text we can see the character as follow, sprang, help, washed, saw, spoke, pushed. The second number of language features is nouns. Types of nouns in this text are proper noun such as, Mangita and Larina. The common nouns such as, fisherman, wife. The collective nouns such as, a bag of seeds, the point of death. The abstract noun such as, kindness. And material noun such as, rice, seed. The third number of language features is adjectives. Adjectives in the text consist of personality adjectives such as, cruel, Kind, Physical appearance such as, black, dark. And the comparative adjectives such as, worse and worse. The fourth number of language features is adverbs. Adverbs in this text are adverb of manner such as, cruelly, mockingly, finally, suddenly. Adverb of place such as, down, there, the bottom, everywhere. Adverb of time such as, now. And adverbs of frequency such as, never.

The Golden Star Fruit Tree is a famous story from Vietnam. The language features of this story can be seeing from the table below:

Table 8. The Golden Star Fruit Tree short story

\begin{tabular}{|c|c|c|c|}
\hline \multicolumn{4}{|c|}{ Language features } \\
\hline Nouns & Verbs & Adjectives & Adverbs \\
\hline Vietnam & Died & Rich & A long time ago \\
Sons & Divided & Old & In front of \\
Attitudes & Took & Different & There \\
Older brother & Gave & Greedy & Unfortunately \\
Younger brother & Made & Kind & One day \\
Father's wealth & Came & Big & Surprisingly \\
Parts & Ate & Afraid & Too \\
Everything & Know & Long & Happily \\
A smal piece of land & Dared & Poor & Finally \\
Star fruit tree & Approach & Happy & Now \\
The tree & Begged & Same & Soon \\
Raven & Replied & Longer & On the way \\
All the ripe fruit & Need & Heavy & Down \\
The market & Have & Straight & \\
Family & Bring & Fast & \\
Bag & Fill & & \\
A place full of gold & Told & & \\
Raven's back & Climbed & & \\
House & Flew & & \\
Wife & Invited & & \\
Younger brother's & Refused & & \\
house & Decided & & \\
Wealth & Got & & \\
The truth & Surprised & & \\
& & & \\
\hline
\end{tabular}




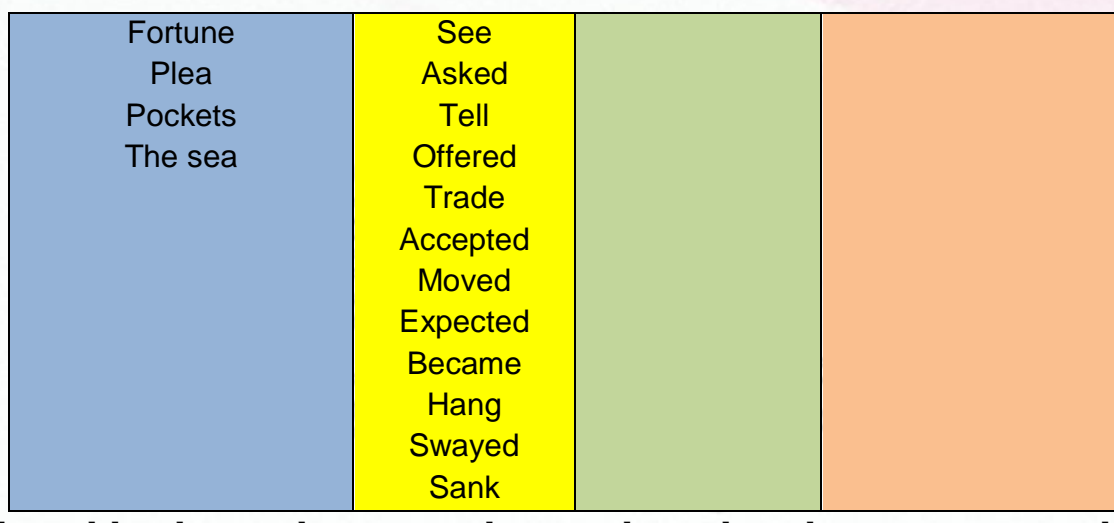

From the table above, the researcher analyze that the greatest numbers of language features are verbs. The characters of this short story can be see from verb as follow; took, gave, filled, brought, tell. The second number of language features is nouns. Nouns in this short story consist of proper noun such as, Vietnam, raven. The next noun is common coun such as sons, brother. The third noun is collective noun such as a small piece of land, a place full of gold. The last noun is material noun such as, gold. The third number of language features is adjectives. Adjectives in this short story consist of phisical appearance such as, big, rich, and old. The personality adjectives such as, greedy, kind. The last adjectives are descriptive in comparative form, such as, longer. The fourth number of language features is adverb. The adverbs using adverb of manner such as, surprisingly, finally. Adverb of place such as, in front of, there. Adverb of time such as, one day. And adverb of frequency such as, soon, too.

3. The Empty Pot

The Empty pot is a folktale from China. The language features of this short story can be see from the table below:

Table 9. The Empty Pot short story

\begin{tabular}{|c|c|c|c|}
\hline \multicolumn{4}{|c|}{ Language features } \\
\hline Nouns & Verbs & Adjectives & Adverbs \\
\hline An emperor & Needed & Old & Once upon a time \\
A successor & Select & Best & Next \\
Throne & Loved & Good & Carefully \\
Children & Decided & Young & Properly \\
Flowers & Call & A tiny & One week later \\
Plants & Gave & The same & Sprouting \\
Kingdom & Said & Confused & Carefully \\
Seed & Show & Finest & At the palace \\
Child & Win & Empty & Again \\
Result & Wear & Real & \\
Months & Wanted & Shame & \\
Contest & Returned & Blossoming & \\
Crown & Carried & Honest & \\
Crowd & Put & enough & \\
Palace & Tried & & \\
Home & Announced & & \\
One of the children & Emerged & & \\
Jhrunk & Changed & & \\
Gardener & Grow & & \\
Village & Repotted & & \\
\hline
\end{tabular}




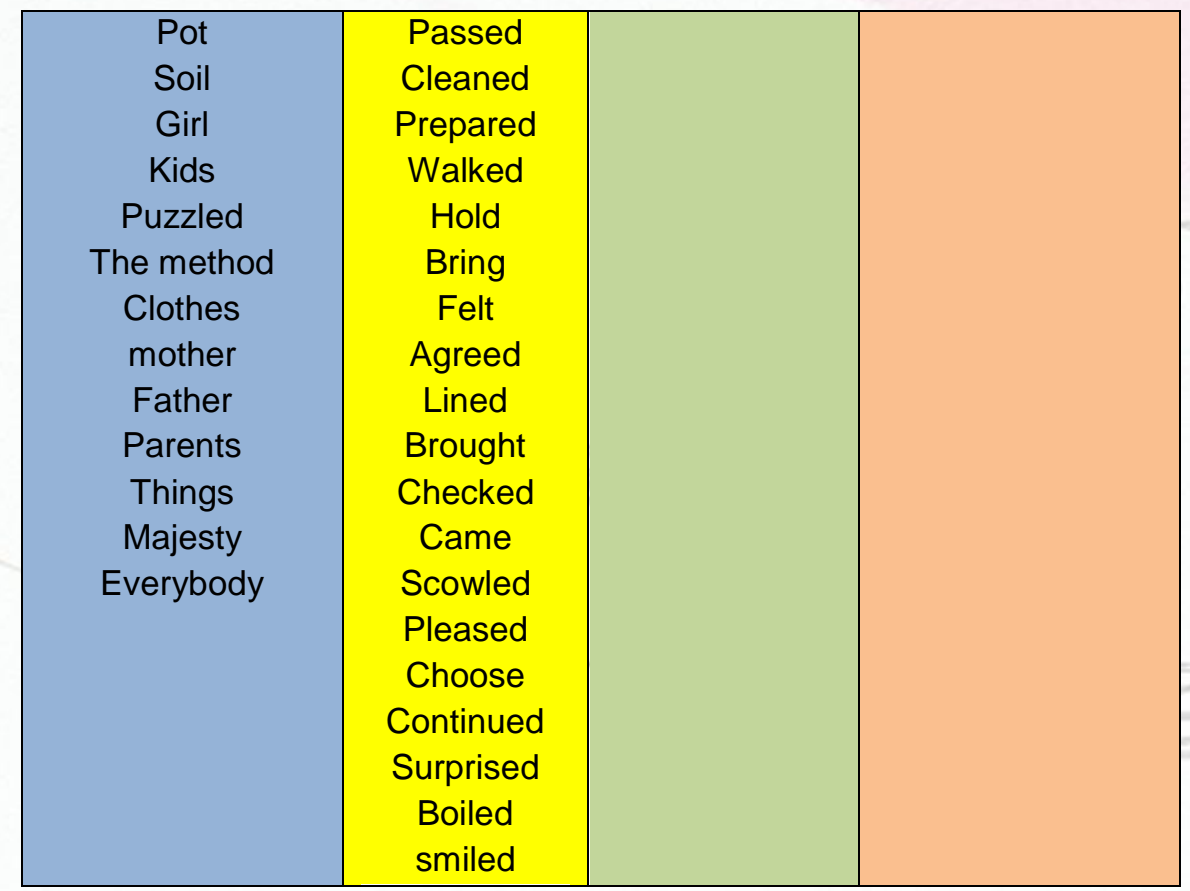

From the text above, researcher analyze that the greatest number of language features are verbs. We can see the character from verbs such as, felt, agreed, said, and tried. The second number of language features is noun. In this short story the author use proper noun such as, Jhronk. Common noun such as, the emperor. Collective noun such as, one of the children. The material noun such as, seed. The third number of language is adjectives. The adjectives consist of personality adjective such as honest. The other adjective is physical appearance such as, old. The fourth number of language features is adverbs. The author use adverb of manner such as, carefully, properly. Adverb of place such as, at the palace, once upon a time. The adverb of frequency such as, again.

\section{Beauty and the Beast}

Beauty and the Beast is one of famous folktales in the world. The language features in this short story can be seeing in the table below:

Table 10. Beauty and the Beast short story

\begin{tabular}{|c|c|c|c|}
\hline \multicolumn{4}{|c|}{ Language features } \\
\hline Nouns & Verbs & Adjectives & Adverbs \\
\hline A merchant & Became & Youngest & Once upon a time \\
Daughters & Worked & Most & The night \\
Sons & Took & Beautiful & Morning \\
girl & Demanded & Lost & Evening \\
The family & Bring & Poor & Never \\
Money & Asked & Hard & One day \\
Beauty & Regain & Expensive & Night \\
Brothers & Trapped & Simply & Gladly \\
Sisters & Came & Perfect & Suddenly \\
Wealth & Found & Jealous & Happily \\
Older sister & Wandered & Broken & \\
Garments & Saw & & \\
Rose & Plucked & & \\
Father & Appears & & \\
The forest & Said & & \\
The snow storm & Die & & \\
\hline
\end{tabular}




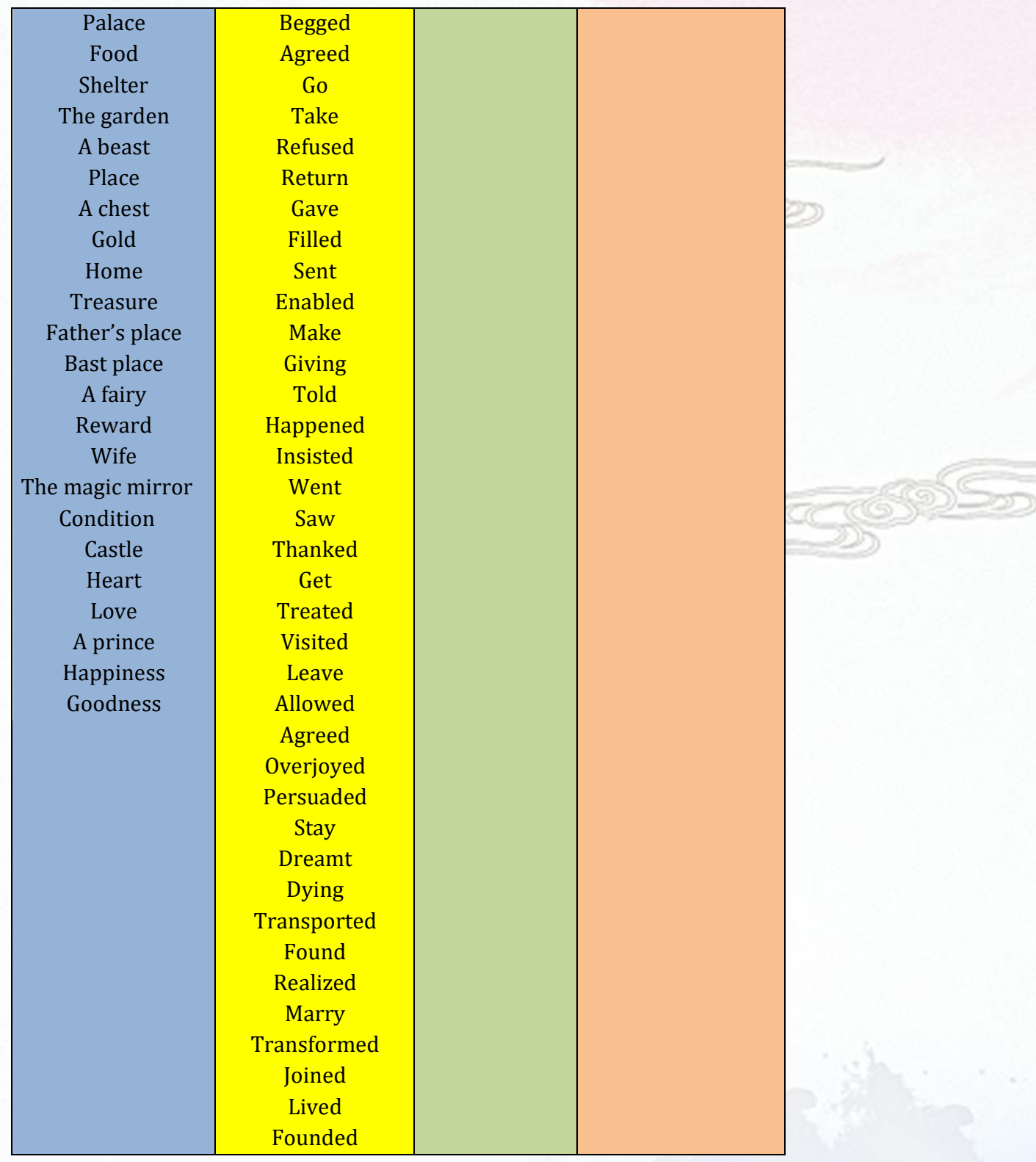

From the table above, the greatest number of language features is verbs. Verbs in the text such as, became, worked, came, die, refused, thanked, transformed, etc. The second greatest number of language features is nouns. The types of noun in this text are proper noun such as, Beauty, rose. The common noun such as, merchant, daughters, sons. Abstract noun such as, happiness, goodness. And the last is material noun such as, gold. Adjectives are the third numbers of language features although it is only one point greater from adverbs. There are three types of adjectives in the text; they are physical appearance, superlative adjective and personality adjective. Such as, the youngest, the most beautiful. The youngest and the most are superlative adjective while beautiful is physical appearance adjective. Personality adjective such as, jealous. The fourth number of language features is adverbs. Adverbs in this text consist of adverb of manner such as, suddenly. Adverb of time such as, every evening. And adverb of frequency such as, never.

\section{The Woodman and His Children}


The Woodman and His Children is a famous folktale in the world. The original title is Henzel and Gretel. The language features of this short story can be seeing in the table as follows;

Table 11. The Woodman and His Children short story

\begin{tabular}{|c|c|c|c|}
\hline \multicolumn{4}{|c|}{ Language features } \\
\hline Nouns & Verbs & Adjectives & Adverbs \\
\hline A woodman & Lived & Bad & Once \\
\hline A mountain & Went & Poorer & Everyday \\
\hline The forest & Cut & Deep & After a while \\
\hline Wood & Had & Small short & Finally \\
\hline Children & Died & Lost & One day \\
\hline Boy & Married & Nice & Somewhere \\
\hline Henzel & Became & Sweet & Morning \\
\hline Gretel & Find & Clear & Here \\
\hline The mother & Buy & Hungry & In the evening \\
\hline Father & Grew & Unusual & The end of the day \\
\hline Woman & Suggested & Poor & Now \\
\hline Wife & Abandon & Obvious & Aimlessly \\
\hline Woodcutter & Objected & Delicious & Naturally \\
\hline Stepmother & Kept & Fatten & Simply \\
\hline Person & Talking & Long & Day after day \\
\hline Customers & Made & Thin & Inside \\
\hline Firewood & Overhead & Hot & There \\
\hline Family & Collected & Good & Finally \\
\hline Husband & Filled & Valuable & Again \\
\hline Idea & Sleep & Took & \\
\hline The plan & Reached & Apologized & \\
\hline Child & Said & Longer & \\
\hline Pebbles & Stay & Poor & \\
\hline Pocket & Play & Rich & \\
\hline Shirtfront & Return & happy & \\
\hline Home & Walked & & \\
\hline A piece of bread & Dropped & & \\
\hline Place & Brought & & \\
\hline The parents & Began & & \\
\hline Distances & Mark & & \\
\hline The trail & Tried & & \\
\hline Destination & Disappeared & & \\
\hline All of the pebbles & Eaten & & \\
\hline Crumbs of bread & Wandered & & \\
\hline Ground & Belonged & & \\
\hline Birds & Made & & \\
\hline House of a witch & Attracted & & \\
\hline Candy & Opened & & \\
\hline Foods & Entered & & \\
\hline The roof & Grabbed & & \\
\hline Chocolate & Put & & \\
\hline The walls & Became & & \\
\hline Cake & Cook & & \\
\hline Windowpanes & Took & & \\
\hline Sugar & Withdraw & & \\
\hline Building & Grown & & \\
\hline A piece of roof & Feel & & \\
\hline One of the & Fed & & \\
\hline windowpanes & Remain & & \\
\hline Doorknob & Annoyed & & \\
\hline
\end{tabular}




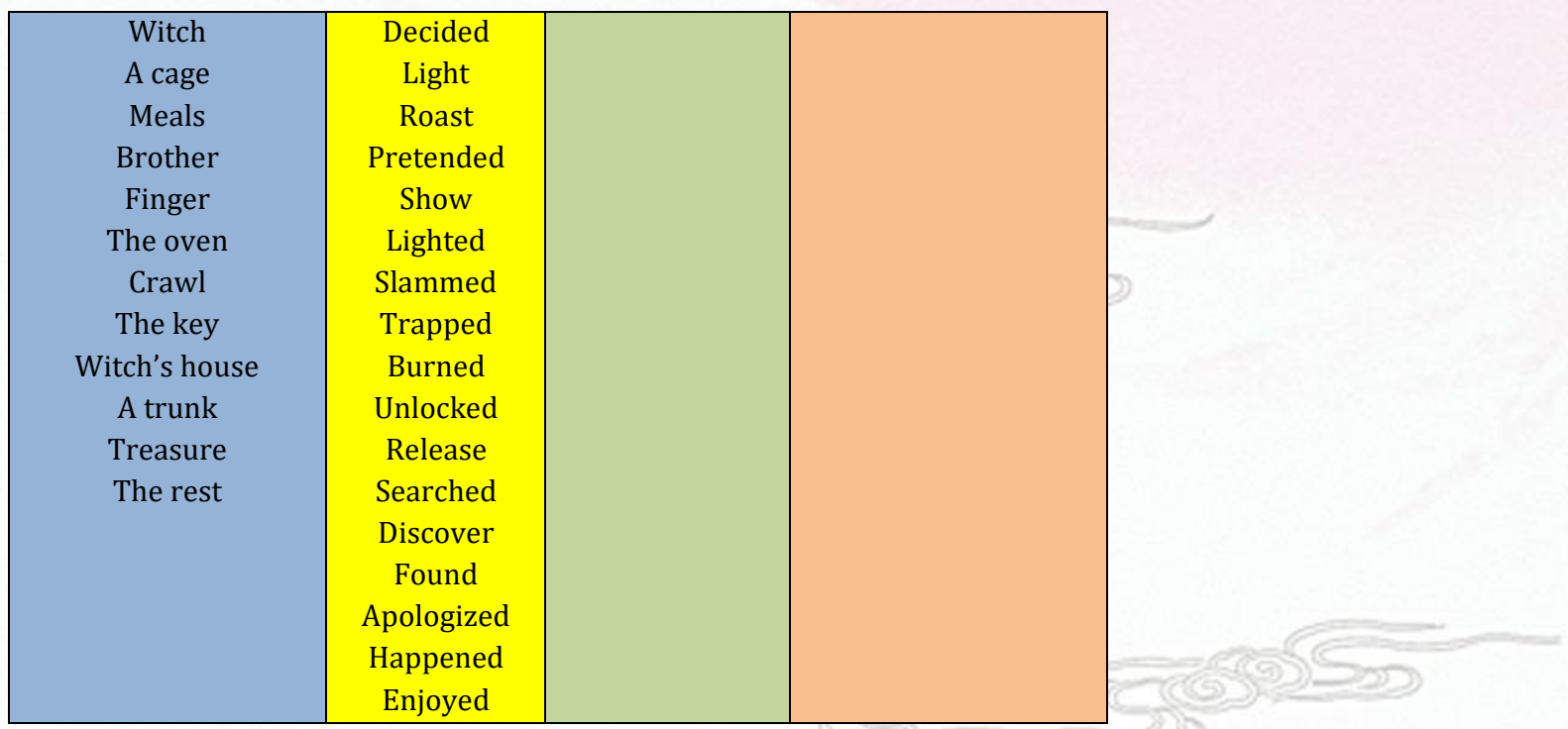

From the table above, the researcher analyze that the greatest number of language features in this short story are verbs. The characters in this story can be seeing from the verbs such as, dropped, have, slammed, shut, and trapped. The second number of language features is nouns. Noun which use in this short story are proper nouns such as, Henzel, Gretel. Common noun such as, woodman, mountain. Collective noun such as, a piece of the roof, one of the windowpanes. The material noun such as, the doorknob, the door. The third number of language features is adjectives. The adjective use physical appearance such as, fat. The personality adjective such as, bad. The comparative adjective such as, longer. The last number of language features is adverbs. The adverbs in this text are adverb of manner such as, aimlessly. The adverb of place such as, here. The adverb of time such as, morning.

\section{The Prince and his Best Friends}

The Prince and his Best Friends is about the frienship of three young mans. The language features of this short story can be seeing from the table below:

Table 12. The Prince and his Best Friends short story

\begin{tabular}{|c|c|c|c|}
\hline \multicolumn{4}{|c|}{ Language features } \\
\hline Nouns & Verbs & Adjectives & Adverbs \\
\hline Prince & Adored & Kind & Once upon a time \\
Jonathan & Walking & Young & One day \\
Loved & Attacked & Old & Suddenly \\
People & Entered & Afraid & Near \\
Friends & Blockaded & Suspicious & Inside \\
Peter Pipe & Trapped & angry & Immediately \\
The servant of the palace & Terrified & & Quietly \\
Franklin Greedy & Asked & & Early at dawn \\
A son of aristocrat & Surrender & & The front \\
The forest & Urged & & There \\
A group of bandits & Supported & & Suddenly \\
Three boys & Give & & Outside \\
House & Decided & & Behind \\
The gate & Realised & & Safely \\
Doors & Become & & \\
The three boys & Ask & & \\
A hostage & Scared & & \\
The bandits & Wanted & & \\
Ransom & Make & & \\
& & & \\
\hline
\end{tabular}



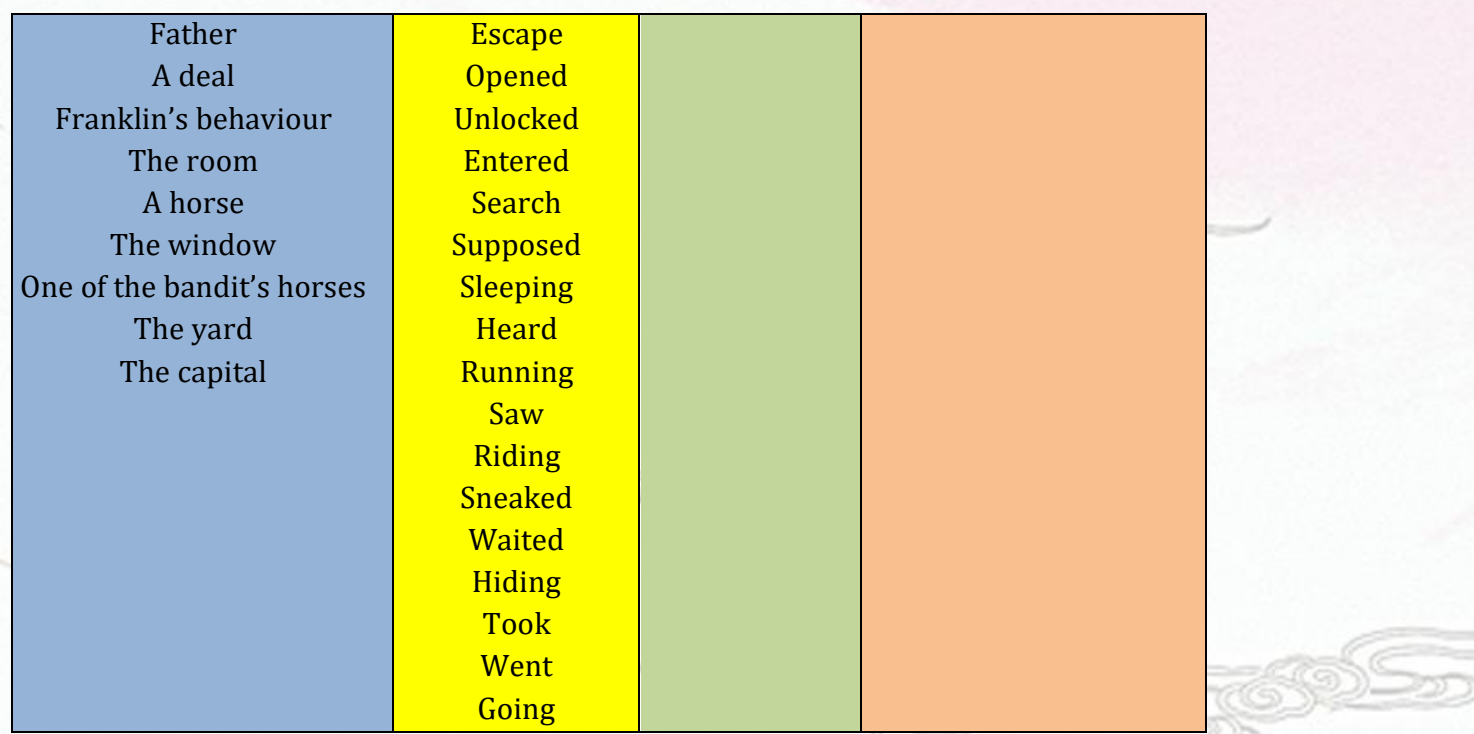

From the table above, the greatest number of language features are verbs, The verbs such as, decided, realized, become, made, opened, unlocked.

The second greates number of language features is nouns. Nouns which used in this short story are proper noun and common noun such as, prince, Jonathan. From the verbs Jonathan is proper noun and prince is common noun. The collective noun such as, the servant of the palace, the son of an aristocrat.

The third number of language features is adverbs. In this short story, the authors used adverbs of manner such as, immediately. The adverb of place such as, inside. The adverb of time such as Early at dawn. The last number of language features is adjectives such as, kind, young. Adjectives kind is personality adjectives and young is physical appearance.

\section{The major character characterized in the short stories.}

a. Indonesian short story.

Having analyze the result, the researcher find that Timun Emas is the major character in this short story. The major character in a story is generally known as protagonist. She is protagonist because she is a hero in this story and it can be see from verbs run, spread, and threw. Such as in the sentence finally, when Timun Emas was almost caught, she threw her salt. Soon the land where Buta Ijo stood turned into ocean. Buto Ijo was drowned and died instantly (line 32). Timun Emas has dynamic character who changes from frightened to be brave girl. It also can be see from verbs such as frightened and scared. Timun Emas was scared but because of his weapons she could kill a monster. Timun Emas also has neutral character, who describes the imaginary character that is only life in the fiction.

Malin Kundang is the major character, he is the most appear in the story. Malin Kundang is antagonist because he has bad character. It can see from verbs go away and shouted. He shouted to his mother to let her mother go away. From adjective ashamed, he ashamed to his wife because his mother is very poor. Malin Kundang has dynamic character that changes the action it can see from. It can 
see from adjectives poor, good, diligent and rich. Malin has good character before, he is good and diligent but after he become rich, he changes to be a bad character. Malin Kundang is neutral character; this character is only presented to set up the story itself.

In The Crying Stone short story, a daughter is the major character but she is antagonist. It can see from adjectives lazy and arrogant. And from noun servant, she calls her mother as her servant. The character of a daughter can be see from the quotation "No, she is not my mother. She is my servant," the girl answered (line 14). A daughter has flat character that has only one certain nature character that is bad character. A daughter also static character, it is the same from beginning until the end because the conflict of the story does not influent to this character. a daughter is neutral character because this character is only presented to set up the story itself.

The major character in the short story of The Legend of Kemaro Island is Tan Bun Ann because he is the most appears in the story. He is protagonist. It can see from the nouns love and courage. Tan Bun Ann fall in love with Siti Fatimah and he has courage to propose her. From the verbs such as, permission, admired and propose. The character of Tan Bun Ann can be seen in the sentences Tan Bun Ann finally got information about Fatimah. He knew that she was single and the king only wanted to have a rich son in law. The information made Tan Bun Ann worked harder. He wants to be richer (line 15). Tan Bun Ann is flat character because he has simple character. The character of Tan Bun Ann always static that is does not change in surprising way. Tan Bun Ann is neutral character who describes the imaginary character that is only life in the fiction.

Wa Lancar is the major character in Wa Lancar short story. He has good character, its mean that Wa Lancar is protagonist. It can see from verbs studied, help, teaching and remembered. The character of Wa Lancar can be seen from the sentence Wa Lancar wanted to help poor kids by teaching them (line 14). Wa Lancar is flat character because it is only has one nature character. There is no surprising action designed to make the reader impressed. Wa Lancar also stactic because the character remains predictable. Wa Lancar is neutral character; he describes the imaginary character that is only life in the fiction

The major character in The Legend of Rawa Pening is a little poor boy. The little boy is protagonist. It can see from adjectives little, poor, hungry and weak. Such as in the sentences Once upon a time, there was a little poor boy came into a village. He was very hungry and weak (line 1). From verbs such as, used and pick up for example in the sentence he used the "Lesung" as a boat and picked up the old woman (line 15) a little boy has flat character, he has the simple character. A little boy has dynamic character, his character changes from weak to be strong. A little boy is neutral character.

b. English Short Story.

Mangita and Larina are two major characters in Mangita and Larina's short story. There are two characters in this short story, that are good and bad characters. Mangita has good character and she is protagonist, it can see from 
adjectives good and kind. For example in the sentence she was a good and beautiful girl (line 3). And you were cruel and Mangita was kind (line 41). It can see from nouns such as, loved and kindness. For example in the sentence she was a good and beautiful girl, was loved by all for her kindness. From verbs such as, help and washed. For example Mangita sprang to help her, washed the blood away from her head (line 15). Opposite with Mangita, Larina is antagonist. It can see from adjective jealous and cruel, such as This made Larina jealous (line 10) and the cruel girl said that she had done so (line 37 ). From verbs such as stick, laugh, spoke and pushed, for example in the sentences, she would catch a pretty butterfly, cruelly stick a pin through it (line 7). ...and would laugh to see the poor butterfly struggling in the pain (line 9). When Larita saw the old woman she spoke mockingly to her and pushed her. (line 14). And adver such as cruelly, for example in the sentence the people dislike her for her cruelly (line 9). The character of Mangita and Larina are also flat characters, the attitude and behavior of the character is totally flat. There is no surprising action. Both of them also static that is do not changed in surprisingly way. The major characters in this short story are neutral character because this character is only presented to set up the story itself.

In The Golden Star Fruit Tree short story, there are two major characters that are the older brother and the younger brother. The older brother is antagonist, he has bad character. It can see from adjective greedy in the sentences such as, the older brother was very greedy (line 2). From verbs took and gave from the sentence such as, the big brother took almost everything. He gave his younger brother only a small piece of land (line 5). Opposite from his brother, the younger brother is protagonist and he has good character. It can see from adjective kind such as ....and the younger brother was very kind (line 3 ). From verb invited such as, on the commemoration of his father's death, he invited his older to come to his house (line 22). Both of them have flat character, it means that they are the simple character that only has nature character. Their characters also static, their characters remains predictable. The major characters have neutral characters because this character is only presented to set up the story itself.

In The Empty Pot short story, Jhrunk is major character. He is protagonist because he has good character. It can see from adjectives good, best and honest such as in the sentence He was a good gardener, even people said that he was the best young gardener in his village (line 10) and sentence "you are the only child honest enough to return with an empty pot" (line 48). From verbs tried and planted such as, ". I tried the best. I planted your seed with the best soil..." (Line 44), it means that Jhrunk is dilligent child. Jhrunk also flat character, he has simple character, there is no surprising action. The character of Jhrunk is static because his character is the same at the end of the story as the beginning. Jhrunk is neutral character who describes the imaginary character that is only life in the fiction

Beauty is the major character in Beauty and the Beast short story. Beauty is protagonist, she has good character. It can see from verbs insisted and went such as, Beauty insisted on taking her father's place, 
and so she went to the Beast palace (line 15). Beauty has dynamic character, who demonstrated a new realization about her self. Beast asks Beauty to be his wife but Beauty refused him. At the end, Beauty realized that she was in love with the Beast and want to marry him. Beauty is neutral character who describes the imaginary character that is only life in the fiction

In the short story of The Woodman and His Children, there are two major characters that are Henzel and Gretel. Henzel and Gretel has good characters and they are protagonists. Henzel and Gretel are the heroes, it can see from verbs slammed, shut, and trapped such as, Gretel Slummed shut the oven door and trapped the witch inside (line 45). Henzel and Gretel are dynamic characters, their characters change to be brave characters.

\section{Discussion}

\section{The $e^{\text {malocranatastin }}$ Indonesian Short Sories}

Having analyzed the Indonesian short stories, the researcher found that the major character in Indonesian short stories has two characters, protagonist and antagonist characters. Although they are from different regions, some of them have the same characters, such as Malin Kundang and The Crying Stone. Both of them have bad attitudes, they are ungodly children. Different from Malin Kundang and The Crying Stone, Timun Emas, Wa Lancar and The Legend of Rawa Pening have good attitudes; they are heroes and want to help another people. The Kemaro Island is about a couple falling in love but they are never being in love because of
Henzel and Gretel has neutral characters, they describes the imaginary character who is only life in the fiction

The major character in The Prince and his Best Friends short story are Jonathan and Peter Piper. They are protagonist characters and have good characters. It can see from adjective kind and afraid such as ...there lived a kind young prince named Jonathan (line 1) and ...but Peter was not afraid (line 8). Jonathan and Peter Piper have Dynamic character, which changes in the course of the action. They also has neutral character who describes the imaginary character who is only life in the fiction

death. From the six short stories, four of them, Malin Kundang, The Crying Stone, The Legend of Kemaro Island and The Legend of Rawa Pening have the real evidence.

\section{The Major Characters in English Short Sories}

From six English short stories four of them have two major characters in one short story, they are protagonist and antagonist. The short stories such as, Mangita and Larina, The Golden Star Fruit Tree, The Woodman and His Children and The Prince and His Best Friends. The major characters of each short story have bad and good attitudes. Two of short stories have one major character in one short story, that 
are Beauty and the Beast and The Empty Pot.

From the twelve short stories, the researcher has analyzed that there is no ungodly characters in English short story such as Malin Kundang and The Crying Stone. But there are the same character between Timun Emas, The Empty Pot and The Woodmand and His Children; they are about honest, brave and hero children. They are about kind children.

\section{The Major Characters characterized short stories}

From the explanation in the result, researcher analyze that in Indonesian short stories Timun Emas has protagonist, dynamic and neutral characters. Malin Kundang has antagonist, dynamic and neutral characters. The Crying stone has antagonist, flat, static and neutral characters. The Legend of Kemaro Island has protagonist, flat and neutral characters. Wa Lancar has protagonist, flat and neutral characters. And the Legend of Rawa Pening has protagonist, flat, dynamic and neutral characters.

There are four short stories which have almost same characters that are Timun Emas, The Legend of Kemaro Island, Wa Lancar, and The Legend of Rawa Pening. The major characters of each short story are protagonist and neutral characters. But each of them has different in flat, static and dynamic characters. Timun Emas has dynamic character same withThe Legend of Rawa Pening. The Legend of Kemaro Island, Wa Lancar and The Legend of Rawa Pening have flat characters
In English short stories, Mangita and Larina short story has the same characters with The Golden Star Fruit Tree and The Empty Pot. Both of them have two major characters, they are protagonist and antagonist, flat, static, and neutral characters. But The Empty Pot only has one major character. The Beauty and the Beast short story have same characters with The Woodman and His Children and The Prince and his Best Fiends. The major characters of that stories has protagonist, dynamic and neutral characters.

\section{Explaining the result with theory}

In this paper attempts have been made to language features analyze in selected short stories. In order to carry out the language features, twelve different short stories (Timun Emas, Malin Kundang, The Legend of Kemaro Island, The Legend of Rawa Pening, The Crying Stone, Wa Lancar, Mangita and Larina, The Golden Star Fruit Tree, Beauty and the Beast and The Woodman and the Children (Hanzel and Gretel), The Prince and his Best Friends) a checklist of language features categories suggested by Leech and Short (2007) has been applied as a theoretical framework.

In the analysis of Indonesian short stories among the checklists, lexical categories have been employed. And it was noticed that the authors use of verbs takes the largest share of the major word classes. These verbs play a very great role in describing the characters, the setting and the surroundings well. Through the use of adjectives (that contributes the 3rd largest number from the major word classes), the author is able to describe the physical and psychological features of the characters and the setting. Nouns, the second largest 
group of the major word classes, have played an important role in the story. This role in making meaning accessible to the reader is achieved through describing actions and to a certain extent by playing stative role in the story. The fourth number is adverbs.

In the analysis of English short stories among the checklists, lexical categories have been employed. Same with the Indonesian short stories, There are six English short stories use of verbs takes the largest share of the major word classes and nouns are the second largest group of the major word classes. The second number is verbs. All of English short stories, adjectives that contributes the 3rd largest number from the major word classes, the author is able to describe the physical and psychological features of the characters. The fourth number is adverbs. From the explanation above, the researcher needs to compare the language features by using the table as follows:

Table 13. The number of language features in Indonesian and English short stories.

\begin{tabular}{|c|c|c|c|c|c|c|c|c|c|}
\hline \multirow{2}{*}{$\begin{array}{l}\text { Indonesian } \\
\text { Short Stories }\end{array}$} & \multicolumn{4}{|c|}{ Language Features } & \multirow{2}{*}{$\begin{array}{c}\text { English short } \\
\text { stories }\end{array}$} & \multicolumn{4}{|c|}{ Language Features } \\
\hline & $\mathbf{N}$ & $\mathbf{V}$ & Adj & Adv & & $\mathbf{N}$ & $\mathbf{V}$ & Adj & Adv \\
\hline Timun Emas & 37 & 46 & 17 & 9 & $\begin{array}{l}\text { Mangita and } \\
\text { Larina }\end{array}$ & 63 & 75 & 26 & 19 \\
\hline Malin Kundang & 33 & 44 & 18 & 9 & $\begin{array}{c}\text { The Golden Star } \\
\text { Fruit Tree }\end{array}$ & 30 & 37 & 16 & 14 \\
\hline $\begin{array}{c}\text { Tle Legend of } \\
\text { Kemaro Island }\end{array}$ & 39 & 42 & 17 & 16 & The Empty Pot & 32 & 38 & 14 & 9 \\
\hline The Crying Stone & 22 & 31 & 15 & 17 & $\begin{array}{c}\text { Beauty and the } \\
\text { Beast }\end{array}$ & 39 & 53 & 11 & 10 \\
\hline Wa Lancar & 36 & 41 & 18 & 15 & $\begin{array}{l}\text { The Woodman } \\
\text { and His children }\end{array}$ & 62 & 67 & 25 & 19 \\
\hline $\begin{array}{l}\text { The Legend of } \\
\text { Rawa Pening }\end{array}$ & 28 & 33 & 12 & 6 & $\begin{array}{l}\text { The Prince and } \\
\text { his Best Friend }\end{array}$ & 29 & 36 & 6 & 14 \\
\hline Total & 195 & 237 & 97 & 72 & Total & 255 & 306 & 98 & 85 \\
\hline
\end{tabular}

From the table above, the researcher analyze that from all of the stories, the authors of Indonesian and English short story use verbs as the greatest number of language features, the second numbers are nouns, the third numbers are adectives and the fourth numbers are adverbs. The number of English short stories is greater than the Indonesian short stories. In The Crying Stone and The Prince and his Best Friends short stories, the numbers of adverbs are larger than adjectives.

\section{The Comparing and Constrasting Result with Other Study}

From the previous studies in chapter I, This study gets the same result from Alemu (2015) about Stylistic Analysis of Selected Short Stories by O Henry. Alemu analized four short stories of $\mathrm{O}$ Henry (After Twenty Years, A Harlem Tragedy, The Last Leaf, and A Furnished Room). He use the same theory from Short and Leech (2007). The result of Alemu's paper is in one the short story, After Twenty Years, the author's use of nouns takes the largest share of the major word classes. Verbs are the second dominant group of the major word classes. Adjectives contribute the 3rd largest number from the major word classes. And the least 
represented in the major word classes are adverbs.

\section{The Implication of this research for study}

The implications of this research for study are firstly, for the teacher, short story is one of materials that used to be taught in Junior High School level especially for ninth grade. According to Permendikbud number 24 (2016) in syllabus about core competence $(1,2,3,4)$ and basic competence (3.7 and 4.7) for the ninth grade of Junior High School. The unit focus on narrative text. The grammar lessons are the use of simple past tense, adverbs of time in simple past tense, singular and plural nouns. The learning material sections contain text title, the social function of the text, language features, vocabulary and the generic structure of the genre. The core competencies and basic competencies of ninth grade at Junior High School are presented as follows:

Table 14. The core competencies and basic competencies of Grade IX of Junior High School.

\begin{tabular}{|c|c|}
\hline CORE COMPETENCIES & BASIC COMPETENCIES \\
\hline $\begin{array}{l}\text { 1. Respect and appreciate the teachings of their religion } \\
\text { 2. Respect and appreciate the honest behaviour, discipline, } \\
\text { responcible, caring (tolerance, mutual cooperation), polite, } \\
\text { confident in teaching effectively with the social and natural } \\
\text { environment in a range of social and existence. } \\
\text { 3. Understanding knowledge (factual, concept science, } \\
\text { technology, arts, conceptual and procedural) based on his } \\
\text { curiosity about science, technology, arts, culture and events } \\
\text { related phenomena. } \\
\text { Try, process, and present in the realm of concrete (using } \\
\text { parse, compose, modify, and create) and realm of the } \\
\text { abstract (writing, reading, counting, drawing, and } \\
\text { fabricated) accordingly to the learned in school and other } \\
\text { sources in the same viewpoint/ theory. }\end{array}$ & $\begin{array}{l}\text { 3.7. To compare the social function, generic } \\
\text { structure, and language features of spoken } \\
\text { and written narrative text by asking and } \\
\text { giving information about short and simple } \\
\text { fairy tales based on the context. }\end{array}$ \\
\hline
\end{tabular}

\section{CONCLUSION}

Having analysed this study about Language Features Used to Describe Major Characters in Short Stories, The language features can be used in teaching narrative texts for children. It could be read in following discussion:

1. The result of language features in Indonesian short stories are the authors use verbs as the largest share of the major word classes. The verbs play a role in describing the characters of major character; the second dominant group of the major word classes are nouns and the third number from the major word classes are adjectives. And the least represented in the major word classes are adverbs. From the six Indonesian short story, there is one short story that has adverb is greater than adjective. It is The Crying Stone short story.

2. In English short stories, the result of language features that used to describe major character has the same result with Indonesian short stories. The authors use verbs as the greatest number of the major word classes, the second 
number is nouns and the third number is adjectives. The last number of the major word classes is adverb, but one of the six English short story, The Prince and His Best Friend short story use adverb as the third number of major word classes and adverb is the last number of major word classes.

3. The dominant characters of major character in Indonesian short stories are protagonist and antagonist, From six of Indonesian short stories, there are two short stories where the major characters are antagonist, they are Malin Kundang and The Crying Stone and four short stories where the major characters are protagonist, they are Timun Emas, The Legend of Kemaro Island, Wa Lancar, and The Legend of Rawa Pening.. In English short stories, there are four short stories which have two major characters, protagonist and antagonist characters, they are Mangita and Larina, The Golden Star Fruit Tree, The Woodman and
His Children, and The Prince and his Friends. . And two short stories only have one character of major character, they are The Empty Pot and Beauty and the Beast, both of these short stories is protagonist. From the twelve short stories, there are no English short stories which have the same characters with Malin Kundang and The Crying stone.

\section{SUGGESTION}

Based on the conclusion above, the researcher would like to give suggestions related to this research, which hopefully will be helpful for English teacher, students, institution, and further researcher.

1. For English teacher, the using of language features to identifying major characters in short stories will help the teacher in teaching narrative text especially for folktales and legends

2. For the students, they expected to be interest with the lesson and easy to identify the major character in short stories, and they can easily to understand the characters of the major characters. the children expected to more interesting to read short stories especially short stories and folktales from Indonesia and another country,

3. Based on the limitation in this study, the result of this research can be used as reference for further researcher who wants to analyse language features and characters of major character in short stories and other literary works.

\section{REFERENCES}

Abrams, M.H. 1971. Glossary of Literary terms. Third Edition. USA: Holt, Rinehart, and Winston, Inc, 1971, Print.

Abrams, M.H. 1999. A Glossary of Literary Terms. United States of America: Heinle \& Heinle. Edisi ke-7

Adane, Samron (2012). Stylistic Analysis of The Beautiful Things that Heaven Bears 
Adera, Diribu (2012). Stylistic Analysis on selected short stories by Edgar Allan Poe

Altenbernd, Lynn and Leslie L Lewis. 1996. A Handbook for the Study of Poetry. London: Collier-Macmillan Limited.

Edgar Allan Poe (1846) “The Phylosophy of Composition”. Graham’s Magazine, 1846

Edgar Allan Poe (1994), from a review of night and morning: A Novel by Edward BulwerLytton, Graham's magazine (April 1841), quoted in May, 1994,66

Esenwein, Berg. 1961. 'What Is a Short-Story', in Current-Garcia and W.R.Patrick (eds.). What Is the Short Story? Chicago, Scott, Foresman.

Hamalian, Leo, and Frederick R. Karl (eds), The Fourth World: The Imprisoned, the Poor, the Sick, the Elderly and Underaged in America (1976).

Kreatif. Bahasa Inggris SMA/MA dan SMK/MAK Kelas X semester 2. Penerbit Viva Pakarindo

Lakoff, G. (1990) Women, Fire and Dangerous Things, Chicago and London: The University of Chicago Press

Leech, G. and Short, M. ([1981] 1992). Style in fiction: A linguistic introduction to English fictional prose. London \& New York: Longman.

Nurgiyantoro B, (2007). Teori Pengkajian Fiksi.Edisi 7; Gajah Mada University, Press

Maxwell, J, A (1996). Qualitative Research Design: An Interactive Approach, London: sage

Sanger, K. ([1998] 2000). The Language of Fiction. London: Routledge.

Sinar Mandiri (2002). Bahasa Inggris. Standar Isi KTSP Kelas IX Semester 2. Penerbit Sinar Mandiri

Wardiman. A, Jahur M.B, \& Djusma. M.S (2008). English in Focus: for Grade IX Junior High School (SMP/MTS), Pusat Perbukuan Departemen Pendidikan dan Kebudayaan

Wellek, Rene and Austin Warren. 1956. Theory of Literature. New York: Hartcourt, Brace and World, Inc.

(2015). Bahasa Inggris. Think Glaobally Act Locally. Kelas IX. Kementerian Pendidikan dan Kebudayaan Republik Indonesia. 2015

- (2016). Peraturan Menteri Pendidikan dan Kebudayaan Nomor 24 Tahun 2016 tentang pendidikan saintifik pada kurikulum 2013 